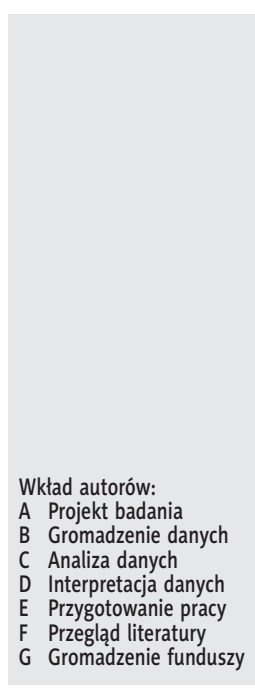

\title{
Lingwistyczne aspekty zaburzeń przetwarzania słuchowego u dzieci i ich rehabilitacja z perspektywy logopedy
}

\section{Linguistic aspects of auditory processing disorders in children and their rehabilitation. Speech therapists' perspective}

\author{
Anna Skoczylas, ${ }^{\text {B,C,EF }}$ \\ Klinika Rehabilitacji, Instytut Fizjologii i Patologii Słuchu, Światowe Centrum Słuchu, \\ Warszawa/Kajetany
}

\section{Streszczenie}

Przetwarzanie słuchowe jest jednym z podstawowych elementów wpływających na rozumienie i produkcję mowy. Rehabilitacja osób borykających się z trudnościami w tym zakresie powinna uwzględniać nie tylko aspekty czysto słuchowe, lecz także związane ze strukturami zdaniowymi, związkami wyrazowymi, a także znaczeniami niesionymi przez słowa i prozodię. Niniejsza praca zawiera propozycje ćwiczeń kształtujących te umiejętności, wykorzystywanych z dobrym efektem w praktyce klinicznej.

Słowa kluczowe: terapia mowy $\bullet$ rozwój mowy $\bullet$ APD $\bullet$ CAPD $\bullet$ procesy przetwarzania słuchowego $\bullet$ percepcja słuchowa $\bullet$ terapia zaburzeń przetwarzania słuchowego $\bullet$ rehabilitacja zaburzeń przetwarzania słuchowego $\bullet$ struktura wypowiedzi $\bullet$ ćwiczenia prozodyczne • ćwiczenia w zakresie percepcji czasu • ćwiczenia w zakresie percepcji wysokości dźwięku • koordynacja słuchowo-ruchowa $\bullet$ trening słuchowy

\begin{abstract} ical practice. pitch perception exercises $\bullet$ auditory - motor coordination $\bullet$ auditory training

\section{Wstęp}

Zaburzenia przetwarzania słuchowego wcześniej zwane centralnymi (lub ośrodkowymi) zaburzeniami przetwarzania słuchowego (ang. (C)APD - (central) auditory processing disorders) są opisywane przez American Speech and Hearing Association jako większe niż przeciętnie trudności w odbiorze i rozumieniu mowy pomimo braku niedosłuchu [1]. Powszechnie wiadomo, że zaburzenia przetwarzania słuchowego manifestują się trudnościami z lokalizacją dźwięków, radzeniem sobie z parametrami czasowymi
\end{abstract}

Auditory processing strongly influences speech perception and production. Rehabilitation of people struggling with disorders should take into account not only purely auditory aspects, but also those related to sentence structures, relations between words and meanings carried by words and prosody. This paper contains suggestions for exercises shaping these skills, used with good effect in clin-

Key words: speech therapy $\bullet$ speech development $\bullet$ APD $\bullet$ CAPD $\bullet$ auditory processing $\bullet$ auditory perception $\bullet$ auditory processing disorders management $\bullet$ auditory processing rehabilitation $\bullet$ sentence structure $\bullet$ prosody exercises $\bullet$ temporal perception exercises $\bullet$

dźwięków, aspektami związanymi z częstotliwością dźwięków, rozumieniem sygnału zubożonego (np. w pomieszczeniach z pogłosem, w głośnym otoczeniu lub dźwięku filtrowanego).

Celem niniejszej publikacji jest przybliżenie lingwistycznych (językoznawczych) aspektów przetwarzania słuchowego i ich wykorzystania w procesie rehabilitacji dzieci, u których rozpoznano APD. Jest to trudne, ponieważ percepcja i rozumienie mowy to procesy niezwykle skomplikowane, przebiegające jednocześnie na

Adres autora: Anna Skoczylas, Światowe Centrum Słuchu, ul. Mokra 17, Kajetany, 05-830 Nadarzyn, e-mail: a.skoczylas@ifps.org.pl 
wielu poziomach (neurologicznym, akustycznym, lingwistycznym), między którymi istnieją liczne zależności. Surmanowicz-Demenko wskazuje kilka etapów percepcji mowy w zależności od typu przetwarzanej informacji: a) akustycznej, b) neuroelektrycznej, c) fonetycznej, d) leksykalnej, e) semantycznej, f) pragmatycznej. Badaczka podkreśla, że przetwarzanie poszczególnych typów informacji uwarunkowane jest hierarchiczną strukturą percepcji mowy [2]. Złożoność procesów związanych z mówieniem, komunikowaniem się jest tak duża, że naukowcy $\mathrm{z}$ różnych dziedzin nie są $\mathrm{w}$ stanie wskazać jednego, wspólnego dla wszystkich modelu percepcji mowy (por. [3-6]). Grabias mową nazywa zespół czynności, jakie przy udziale języka wykonuje człowiek, poznając świat i przekazując jego interpretację innym uczestnikom życia społecznego [7].

Logopedzi, pedagodzy, psycholodzy rehabilitujący osoby z zaburzeniami przetwarzania słuchowego często podkreślają różnicę pomiędzy słyszeniem, które jest procesem pasywnym, zależnym od prawidłowego funkcjonowania ucha i drogi słuchowej, a aktywnym słuchaniem [8]. Słuchanie angażuje dwa typy procesów: wstępujące (bottom-up) i zstępujące (top-down). Procesy wstępujące odnoszą się głównie do wyodrębnienia istotnych cech sygnału, ich analizy i nie wymagają świadomego udziału słuchacza. Procesy zstępujące angażują posiadaną wiedzę, doświadczenie słuchowe i sprawności językowe, w tym umiejętność przypisywania znaczeń, prawidłowego użycia reguł gramatycznych, analizy struktury (np. składni wypowiedzi) $[9,10]$.

Koncepcja przedstawiana przez Grabiasa ujmuje sprawność językową jako nadrzędną wobec czterech innych sprawności:

1. Językowej sprawności systemowej - rozumianej jako stopień opanowania systemu językowego na poziomach: fonologicznym, morfologicznym i składniowym.

2. Językowej sprawności społecznej - pozwalającej na dostosowanie środków językowych do możliwości odbiorcy i funkcji, jaką pełni on w społeczeństwie.

3. Językowej sprawności sytuacyjnej - wiążącej się z wyborem środków językowych odpowiednio do tematu i miejsca rozmowy.

4. Językowej sprawności pragmatycznej - związanej z efektywnością komunikacji, osiąganiem celu założonego przez nadawcę wypowiedzi [11].

Kurkowski wskazuje, że prawidłowy rozwój przetwarzania słuchowego wymaga udziału w nim cztery współdziałających procesów leżących u podstaw tworzenia umiejętności słuchowych: selekcji, dyskryminacji, asocjacji i pamięci. Przy czym selekcja rozumiana jest tu jako umiejętność wyodrębniania dźwięków, dyskryminacja jako umiejętność ich rozróżniania, asocjacja przedstawiana jest jako proces przypisywania znaczeń odpowiednim dźwiękom, natomiast pamięć jako możliwość „magazynowania” informacji werbalnych i swobodnego odwoływania się do nich. Każdy z tych elementów pełni ważną rolę w rozwijaniu zarówno przetwarzania słuchowego, jak i sprawności językowych, kształtujących się w różnych sytuacjach społecznych [8].
Krasowicz-Kupis, zajmująca się w swych badaniach m.in. komunikacją językową, zaobserwowała, że w literaturze z zakresu językoznawstwa system językowy (abstrakcyjny twór istniejący w umyśle każdego użytkownika języka) bywa opisywany na dwa sposoby:

1. Jako zawierający dwa podsystemy: symbole i reguły.

2. Jako zawierający co najmniej cztery główne podsystemy: fonologiczny, morfologiczny, składniowy, semantyczny oraz systemy poboczne (pozostałe), do których autorka zalicza np. podsystem leksykalny i pragmatyczny.

Każdy z tych podsystemów posiada własne reguły, najczęściej przyswajane wraz z wiekiem i doświadczeniem w sposób nieuświadomiony, w różnych sytuacjach społecznych. Najczęściej użytkownicy języka posługują się tymi zasadami sprawnie i bez potrzeby świadomego odwoływania się do swojej wiedzy metajęzykowej [12].

\section{Rodzaje zaburzeń przetwarzania słuchowego u dzieci i ich rehabilitacja}

Zaburzenia przetwarzania słuchowego rzadko występują $\mathrm{w}$ formie izolowanej. W niektórych zaburzeniach, nieprawidłowościach neurorozwojowych trudności w radzeniu sobie z dźwiękiem bywają jednym z symptomów (np. w afazji, dyzartrii, SLI, dysleksji, niektórych chorobach neurodegeneracyjnych) i stanowią część obrazu klinicznego innej choroby bądź stanu. W tych przypadkach nie mówi się o APD, a jedynie włącza odpowiednie, dostosowane do potrzeb pacjenta, ćwiczenia w tok rehabilitacji [13].

Dzieci borykające się z problemem APD doświadczają różnych trudności. Aby wspomóc ich codzienne funkcjonowanie, można wdrożyć szereg zmian dotyczących przekształcenia środowiska (np. stosowanie systemu FM, wprowadzanie zmian architektonicznych likwidujących pogłos), rozpocząć trening słuchowy ukierunkowany na deficyt bądź kształtowanie umiejętności pozwalających na kompensację istniejących zaburzeń. Dlatego też trening dzieci z zaburzeniami przetwarzania słuchowego powinien uwzględniać nie tylko ćwiczenia słuchowe, lecz także gry i zabawy wspomagające koordynację, sprawności językowe czy korzystanie ze wskazówek wielomodalnych.

Ze względu na fakt, że potrzeby dzieci z zaburzeniami przetwarzania słuchowego są niejednorodne, Bellis zaproponowała ich podział na trzy podgrupy i zastosowanie różnych form rehabilitacji zależnie od dominującego problemu:

1. Deficyt w zakresie dekodowania słuchowego.

2. Deficyt prozodyczny.

3. Deficyt integracji [13].

\section{Deficyt dekodowania słuchowego}

U dzieci z deficytem w zakresie dekodowania słuchowego można obserwować niską świadomość fonologiczną, trudność $\mathrm{z}$ radzeniem sobie $\mathrm{z}$ kolejnością zdarzeń akustycznych, co może przekładać się na trudności ze składnią, a przez to negatywnie wpływać na chęć komunikowania 
się, zasób słownika, a w badaniach inteligencji - na znaczną dysproporcję pomiędzy zadaniami werbalnymi i niewerbalnymi na niekorzyść tych pierwszych.

U osób z tego rodzaju zaburzeniami przetwarzania słuchowego rehabilitacja ukierunkowana będzie na kształtowanie świadomości sekwencyjności dźwięków lub ich parametrów np. czasowych, częstotliwościowych, ale też związanych z natężeniem sygnału akustycznego. Aby dzieci te mogły sprawniej kompensować ten deficyt, doradza się również kształtowanie sprawności (nieuświadomionych lub uświadomionych) posługiwania się regułami języka ojczystego.

\section{Deficyt prozodyczny}

W „Słowniku języka polskiego” prozodia opisywana jest jako „ogół brzmieniowych właściwości języka charakteryzujących sylaby lub ich ciągi w toku wypowiedzi”. Prozodia pełni liczne funkcje zarówno lingwistyczne, paralingwistyczne, jak i ekstralingwistyczne. Wysocka do najczęściej wskazywanych funkcji lingwistycznych zalicza:

1. Funkcję segmentacyjną, która towarzyszy strukturze składniowej wypowiedzi.

2. Funkcję delimitacyjną.

3. Uwydatnianie elementów językowych o istotnym dla komunikacji znaczeniu.

4. Sygnalizowanie poszczególnych typów wypowiedzeń za pomocą konturów intonacyjnych (np. wznosząca intonacja w pytaniach).

Wiążą się one ze stosowaniem pauzowania $(1)^{1}$, akcentu leksykalnego $(2)^{2}$ i frazowego $(3)^{3}$. Kontury intonacyjne (4) służą zaś do wskazywania poszczególnych typów wypowiedzeń (np. pytanie, informacja). Funkcje paralingwistyczne autorka wiąże z ekspresją emocji nadawcy i wyrażaniem jego stosunku do odbiorcy, do sytuacji, w jakiej się znajduje, lub samego komunikatu. Funkcje ekstralingwistyczne dotyczą natomiast przenoszenia informacji dotyczących samego nadawcy, jego płci, wieku [14]. Dzieci, u których występuje deficyt prozodyczny, mają trudności z rozumieniem intencji wypowiedzi, zwłaszcza ironii, sarkazmu, żartów zaznaczanych jedynie $\mathrm{w}$ prozodii.

\section{Deficyt integracji}

Powiązany jest $\mathrm{z}$ deficytami w zakresie międzypółkulowej integracji wynikającymi $\mathrm{z}$ wadliwego transferu informacji przenoszonych przez spoidło wielkie [15]. Dzieci z tym deficytem często mają trudności z rozumieniem mowy w obecności tła akustycznego (hałas, szum), z lokalizacją oraz śledzeniem dźwięku. Dodatkowo dzieci te mają problemy w zakresie koordynacji ruchowej, sporządzania notatek, przepisywania oraz

\footnotetext{
${ }^{1}$ Pauzowanie rozumiane jest tu jako stosowanie przerw.

${ }^{2}$ Akcent leksykalny - sylaba wypowiadana w danym słowie nieco głośniej i dłużej od pozostałych. W języku polskim akcent leksykalny zwykle pada na drugą sylabę od końca.

${ }^{3}$ Akcent frazowy - polega na wypowiadaniu najistotniejszego słowa nieco dłużej i głośniej od pozostałych.
}

pisania dyktand, integracji informacji pochodzących $\mathrm{z}$ wielu modalności, nucenia do wskazanej melodii. Jednym ze sposobów rehabilitacji tego typu zaburzeń jest włączenie rehabilitacji ruchowej, np. odpowiednio dobranych ćwiczeń z zakresu integracji sensorycznej czy sensomotoryki.

\section{Propozycje ćwiczeń}

Poniżej zostaną przedstawione ćwiczenia opracowane przez autorkę niniejszego artykułu lub zaczerpnięte $\mathrm{z}$ wybranych pozycji książkowych [16-19]. Wybrano ćwiczenia i wskazano jednocześnie cel i możliwość ich wykorzystania w rehabilitacji określonego deficytu. Oddzielnie ujęto propozycje ćwiczeń kształtujących strategie kompensacyjne. Każde dziecko wymaga odmiennego podejścia i indywidualnego doboru ćwiczeń stymulujących percepcję słuchową lub sprawności językowe, jednak w opinii autorki podział taki może ułatwić prowadzenie treningu.

\section{Ćwiczenie 1}

Cel: Kształtowane percepcji czasu (deficyt w zakresie dekodowania słuchowego), kształtowanie uwagi i pamięci słuchowej.

Instrukcja podawana przez prowadzącego: Powtórz rytm, który usłyszysz.w

Sposób wykonania ćwiczenia: Prowadzący wyklaskuje lub wystukuje dowolnymi przedmiotami krótki rytm. Po zakończeniu krótkiej sekwencji rytmicznej prowadzący podaje dziecku instrument lub przedmiot, za pomocą którego wystukiwany był rytm. Istotne jest, aby w miarę rozwoju umiejętności dziecko coraz rzadziej mogło patrzeć na prowadzącego, gdy ten wystukuje rytm.

\section{Ćwiczenie 2}

Cel: Kształtowanie percepcji czasu (deficyt w zakresie dekodowania słuchowego), kształtowanie uwagi i pamięci słuchowej.

Instrukcja podawana przez prowadzącego: Oglądałeś mecz piłkarski? Czasem podczas meczu kibice skandują i wyklaskują jakiś rytm. Posłuchaj rytmu, który wystukam. Będziemy go powtarzać przez dłuższą chwilę, tak jak to robią kibice.

Sposób wykonania ćwiczenia: Prowadzący wyklaskuje lub wystukuje dowolnymi przedmiotami krótki rytm, powtarza go kilkakrotnie. Dziecko (a w przypadku zajęć grupowych dzieci) dołącza się i próbuje wraz z prowadzącym wystukiwać ten sam rytm.

\section{Ćwiczenie 3}

Cel: Kształtowanie percepcji czasu (deficyt w zakresie dekodowania słuchowego), kształtowanie uwagi i pamięci słuchowej.

Instrukcja podawana przez prowadzącego: Zagwiżdżę dwukrotnie. Powiedz, które gwizdnięcie było krótsze, a które dłuższe. 
Sposób wykonania ćwiczenia: Prowadzący gwiżdże (można użyć fletu, gwizdka itp.). Dziecko mówi, w jakiej kolejności wystąpiły dźwięki: długi i krótki. Wraz z rozwojem umiejętności dziecka można:

a) dodać więcej dźwięków do sekwencji,

b) dodać średni dźwięk, tak by dziecko szeregowało dźwięki od najkrótszego do najdłuższego bądź od najdłuższego do najkrótszego.

\section{Ćwiczenie 4}

Cel: Kształtowanie dyskryminacji dźwięków, uwagi i pamięci słuchowej (deficyt w zakresie dekodowania słuchowego).

Instrukcja podawana przez prowadzącego: Zagramy w memo słuchowe. Potrząsaj opakowaniami, które leżą przed tobą. Spróbuj znaleźć dwa takie same dźwięki. Znalezione pary dźwięków odkładaj na bok.

Na rynku istnieją już zabawki do przeprowadzenia tego ćwiczenia. Można jednak zrobić takie pomoce wraz z dzieckiem, wykorzystując małe identyczne opakowania o nieprzezroczystych ściankach (np. opakowania po małych jogurtach).

\section{Ćwiczenie 5}

Cel: Kształtowanie świadomości fonologicznej i pamięci słuchowej.

Instrukcja podawana przez prowadzącego: Wskaż, w których z podanych słów ukryte jest słowo „pot”. Prowadzący czyta na głos słowa, a słuchacze wskazują w którym $\mathrm{z}$ nich znajduje się poszukiwana cząstka wyrazu

\begin{tabular}{ccc}
\hline potrafi & portmonetka & parokrotny \\
\hline kłopot & łopot & paszport \\
\hline sport & płatki & potężny \\
\hline potok & postawa & płotki \\
\hline potrawa & spotkanie & plotka \\
\hline proteza & potulny & portowy \\
\hline wypośrodkować & potwarz & \\
\hline
\end{tabular}

\section{Ćwiczenie 6}

Cel: Kształtowanie percepcji wysokości dźwięku (deficyt w zakresie dekodowania słuchowego, deficyt prozodyczny), kształtowanie uwagi i pamięci słuchowej.

Instrukcja podawana przez prowadzącego: Zaśpiewam gamę. Posłuchaj i powiedz, czy śpiewałam od najniższego dźwięku do najwyższego czy odwrotnie.

Ponieważ chcemy kształtować percepcję wysokości dźwięków, śpiewamy gamę na „la, la, la”. Unikamy używania nazw dźwięków „do, re, mi, fa, sol, la, si, do”, dlatego, że dzieci, które w szkole mają lekcje muzyki, wiedzą, w jakiej kolejności występują poszczególne nazwy dźwięków w gamie.

Zależnie od możliwości intelektualnych i wieku dziecka nazwy „niższy” i „wyższy” możemy zastąpić nazwami "grubszy” i „cieńszy” bądź „grubszy” i „chudszy”. Staramy się jednak unikać w ćwiczeniach odróżniania wysokości dźwięków nazw „mniejszy” i „większy”, chętnie stosowanych zwłaszcza przez młodsze dzieci. Tych samych nazw dzieci próbują używać przy odróżnianiu długości bądź natężenia dźwięków. Pozwolenie na używanie tych „słów wytrychów” prowadzi do mieszania się kategorii zjawisk akustycznych (długość, wysokość, natężenie), przez co trudniej nabyć i utrwalić umiejętność.

\section{Ćwiczenie 7}

Cel: Kształtowane percepcji wysokości dźwięków, kolejności dźwięków (deficyt w zakresie dekodowania słuchowego, deficyt prozodyczny), kształtowanie uwagi i pamięci słuchowej.

Instrukcja podawana przez prowadzącego: Będą dźwięki „wysoki” i „niski”. Zaśpiewam ich kilka. Posłuchaj i powiedz, w jakiej kolejności je zaśpiewałam.

Zaczynamy od sekwencji dwóch dźwięków. Stopniowo wydłużamy sekwencję, ćwicząc jednocześnie pamięć słuchową dziecka.

Jeśli dziecko ma duży kłopot z nazwaniem dźwięków, na początku treningu może tylko nucić albo spróbować ułożyć sekwencję z wyższych i niższych klocków.

\section{Ćwiczenie 8}

Cel: Kształtowane dyskryminacji i asocjacji dźwięków (deficyt w zakresie dekodowania słuchowego, deficyt prozodyczny), kształtowanie uwagi słuchowej i koordynacji słuchowo- ruchowej (deficyt integracji).

Instrukcja podawana przez prowadzącego: Na nagraniach usłyszysz głosy różnych zwierząt. Niektórych zwierząt możesz nie znać. Posłuchaj i spróbuj wyobrazić sobie to zwierzę, jak się porusza, jaki ma rozmiar, jak się zachowuje. Spróbuj pokazać to zwierzę ruchem.

Prezentujemy dziecku po jednym dźwięku wydawanym przez zwierzę.

Po wykonanym ćwiczeniu warto porozmawiać z dzieckiem na temat jego wyobrażeń słuchowych, na co zwróciło uwagę, czym się różniły nagrania, które nagrania były podobne. Tak poprowadzone ćwiczenie może wspomagać rozwój strategii kompensacyjnych, np. poprzez kształtowanie pól semantycznych, kategoryzowanie, bogacenie słownictwa opisującego.

\section{Ćwiczenie 9}

Cel: Kształtowanie percepcji natężenia i czasu trwania dźwięku (rehabilitacja deficytu prozodycznego), kształtowanie uwagi słuchowej.

Instrukcja podawana przez prowadzącego: Spróbuj wyklaskać lub wytupać rytm piosenki, którą usłyszysz.

Przy wprowadzaniu tego ćwiczenia w tok rehabilitacji najlepiej stosować piosenki dziecięce o bardzo prostym rytmie 
i szybkim tempie (np. znana piosenka „Mydło”, „Szczotka, pasta, kubek” zespołu Fasolki), ponieważ zwłaszcza na początku dzieci próbują wyklaskać nie rytm piosenki, a poszczególne sylaby.

\section{Ćwiczenie 10}

Cel: Kształtowanie percepcji natężenia i czasu trwania dźwięku (rehabilitacja deficytu prozodycznego), kształtowanie uwagi słuchowej.

Instrukcja podawana przez prowadzącego: Będę czytać wiersz takim głosem, jak teraz słyszysz. Klaśnij, kiedy usłyszysz sylabę wypowiadaną głośniej.

Prowadzący czyta dowolną rymowankę lub rytmiczny wiersz dla dzieci, dodatkowo podkreślając głosem (a jeśli to nie wystarczy, także ruchem) akcentowane sylaby, np.

- STOi na STAcji LOkomoTYwa

- CIĘżka, oGROMna i POT z niej SPŁYwa

(Julian Tuwim Lokomotywa)

\section{Ćwiczenie 11}

Cel: Kształtowanie percepcji wysokości, natężenia i czasu trwania dźwięku (rehabilitacja deficytu prozodycznego), kształtowanie uwagi słuchowej.

Instrukcja podawana przez prowadzącego: Wyobraź sobie, że przyleciał na Ziemię Marsjanin. Przyszedł do ciebie i próbuje się z tobą porozumieć. Spróbuj zgadnąć, czy zapytał cię o coś, coś ci kazał zrobić czy opowiadał ci tylko o czymś.

Prowadzący wymyśla zdanie. Wypowiada je, zastępując wszystkie sylaby zdania jedną, np. BA, ale zachowując kontur intonacyjny zdania. Dziecko (lub dzieci) określa, czy wypowiedź była pytaniem, informacją czy nakazem.

\section{Ćwiczenie 12}

Cel: Kształtowanie percepcji wysokości, natężenia i czasu trwania dźwięku (rehabilitacja deficytu prozodycznego), kształtowanie pamięci słuchowej i koordynacji wzrokowo- słuchowo-ruchowej.

Instrukcja podawana przez prowadzącego: Dobierzcie się w pary. Zrobimy małe teatrzyki. Każda para otrzyma na kartce temat. Każdy zespół ułoży „rozmowę bez słów" na zadany temat. Przypomnijcie sobie, jak wyglądają i jak zachowują się ludzie w wymienionych sytuacjach. Za chwilę pokażecie waszą scenkę innym dzieciom. Niestety nie można podczas prezentowania scenki używać słów. Wasze wypowiedzi możecie albo wymruczeć, albo opowiedzieć za pomocą jednej sylaby, pozostawiając jedynie intonację.

Pozostali uczestnicy na podstawie intonacji, mimiki i gestów próbują zgadnąć, co było tematem dialogu. W grze dozwolone jest używanie rekwizytów. Przykładowe zadania:
Właśnie otrzymałeś radosna wiadomość, na która od dawna czekateś.

Przyjechał do Ciebie kolega, którego dawno nie widziałeś.

Przed lecznica dla zwierząt spotykasz sąsiada. Jesteś zasmucony i przybity, bo twój pies jest ciężko chory i nie wiadomo czy wyzdrowieje.

Dostałeś właśnie jedynkę. Jesteś zirytowany, bo uważasz, że otrzymałeś tę ocenę niesprawiedliwie.

Próbujesz wyjaśnić koledze zasady gry, ale on się upiera, żeby grać po swojemu i co chwile wymyśla nowe zasady.

\section{Ćwiczenie 13}

Cel: Kształtowanie pamięci słuchowej i koordynacji słuchowo-ruchowej.

Instrukcja podawana przez prowadzącego: Nauczymy się dziś „piosenki z pokazywaniem” (pląsu). Posłuchajcie, o czym jest, i zastanówcie się, za pomoca jakich gestów moglibyśmy pokazać treść tej piosenki. Kiedy wybierzemy gesty, spróbujemy je połączyć z piosenką.

Początkowo prowadzący śpiewa fragment dowolnej piosenki i uczestnicy zastanawiają się, jak pokazać ruchem treści zawarte w tym fragmencie. Po ustaleniu ruchów prowadzący śpiewa całą piosenkę, a uczestnicy gry pokazują. Po kilkakrotnym zaśpiewaniu uczestnicy gry dołączają do prowadzącego. Cała grupa śpiewa i pokazuje wspólnie. Do wykonania tego ćwiczenia wykorzystuje się pląsy harcerskie, przedszkolne, zuchowe lub inne.

\section{Ćwiczenia kształtujące strategie kompensacyjne}

Dzieci z APD, kiedy dostrzegają, że radzą sobie z mową nieco gorzej niż rówieśnicy, często próbują unikać mówienia, zwłaszcza w sytuacjach, w których czują się niepewnie. Mniejsza liczba produkcji słownych, rzadsze „ćwiczenie mówienia” sprawia, że odpowiednie umiejętności nie są rozwijane. To z kolei prowadzi do wtórnego spowolnienia rozwoju mowy i koło się zamyka. Podobny mechanizm tworzy się na skutek częstego używania urządzeń elektronicznych przez dziecko i jego rodzinę. Już samo włączenie telewizora, który tworzy „tło akustyczne”, sprawia, że ludzie przebywający w jego otoczeniu dużo rzadziej się ze sobą komunikują.

Mniejsza liczba komunikatów, ubóstwo słownika, błędy w zakresie fleksji, składni występujące u rodziców również negatywnie wpływają na rozwój mowy u dziecka. Warto więc zadbać, by rodzice często rozmawiali i ćwiczyli z dzieckiem. Korzyść wówczas będzie obopólna. Wszystkie proponowane poniżej ćwiczenia mają na celu rozwijanie kompetencji i sprawności językowych uczestników.

Na rynku polskim można znaleźć wiele pozycji dotyczących kształtowania percepcji słuchowej dla osób w różnym wieku. Nadal zbyt mało jest jednak pozycji książkowych dotyczących kształtowania strategii kompensacyjnych i odnoszenia się do swoich sprawności językowych, komunikacyjnych i pragmatycznych w momencie, gdy zawodzi percepcja słuchowa. 


\section{Ćwiczenie 1}

Instrukcja podawana przez prowadzącego: Narysowałam rysunek. Spróbuj narysować taki sam. Nie pokażę ci go, ale opowiem, jak go zrobić.

Przykładowo: Narysuj na środku kartki duże koło, a w nim małe kółko. Na środku małego kółka postaw wyraźną kropkę i poprowadź przez nią linie poziomą i pionową, tak by miejsce ich skrzyżowania wyznaczała kropka. To wszystko.

Stopień skomplikowania wzoru, dobór słów, długości zdań oraz zastosowanych struktur składniowych są wyznaczane przez możliwości uczestników. Grę należy prowadzić tak, by to dziecko możliwie jak najczęściej opisywało (dyktowało) wymyślony przez siebie wzór i sprawdzało, czy uczestnicy gry uzyskali takie same wzory. Dziecko może pomagać rysującym tylko za pomocą słów. Żadne pokazywanie wzoru, ani wspomaganie się gestami nie jest dozwolone.

\section{Ćwiczenie 2}

Instrukcja podawana przez prowadzącego: Zasłonię ci szarfą oczy. Nie próbuj jeszcze nigdzie iść. Zrobię w pokoju labirynt z krzeseł. Jeśli zrobisz dokładnie to, o co poproszę, przejdziesz przez labirynt bezpiecznie.

Zadanie polega na przeprowadzaniu osoby z zawiązanymi oczami przez tor przeszkód zbudowany w pokoju, tylko za pomoca instrukcji słownych, w sposób określony przez osobę przeprowadzająca. Przykładowo: Najpierw przejdź dwa kroki do przodu i obróć się w lewo. Następnie zrób dwa żabie skoki do przodu i jeden krok w prawo. Teraz proszę cię, żebyś zrobił cztery stopki do przodu (stopka - krok, w którym palce jednej stopy dotykają do pięty drugiej stopy) itd.

\section{Ćwiczenie 3}

Instrukcja podawana przez prowadzącego: Podam słowo. Spróbuj wskazać takie, które znaczy to samo lub prawie to samo, ale brzmi inaczej. Przykładowo: Kiedy powiem słowo „kartofel”, ty możesz powiedzieć słowo „ziemniak”.

- kartofel - ziemniak

- kubeł - wiadro,

- samochód - auto,

- wesoły - radosny,

- zdziwiony - zaskoczony,

- jabłecznik - szarlotka

- kurz - pył

- flamaster - pisak

- wkręt - śruba

Ćwiczenie ma za zadanie wspierać możliwości dziecka przy transformowaniu informacji, np. gdy dopytuje, czy dobrze zrozumiało wypowiedź rozmówcy. Może być też wykorzystywane do zamieniania słowa zawierającego trudność ortograficzną na łatwiejsze dla danej osoby.

\section{Ćwiczenie 4}

Instrukcja podawana przez prowadzącego: Wybierz jakiś przedmiot i obejrzyj go dokładnie. Spróbuj opisać ten przedmiot, używając sformułowań:

- zarówno ..., jak i ... (np. jest zarówno duży, jak i zielony), - ani ....., ani .... (nie jest ani duży, ani zielony),

- .... a także... (jest duży, a także zielony),

- ...., ale nie .... (jest duży, ale nie zielony).

W wersji dla dzieci młodszych możemy się posłużyć rekwizytami, np. maskotkami, warzywami, owocami, a dla dzieci starszych - figurami geometrycznymi różnej wielkości i w różnych kolorach. Jeśli dzieci nie potrzebują wspomagać się wzrokiem, a ich zasób słownika jest wystarczająco szeroki, możemy wykonywać to ćwiczenie bez rekwizytów. Poniżej umieszczam przykładowe instrukcje, które można podawać starszym przedszkolakom i uczniom młodszych klas, jeśli nie są jeszcze w stanie opisywać wybranej przez nich rzeczy z wykorzystaniem wymienionych powyżej struktur.

Instrukcja podawana przez prowadzącego: Wymień nazwę warzywa, które jest zarówno twarde, jak i brązowe (dziecko powinno wskazać warzywo posiadające obie te cechy, np. ziemniaka). Wymień nazwę owocu, który jest pachnący, ale nie czerwony (dziecko może wskazać zarówno pomarańczę, cytrynę, jak i banana). Wymień nazwę warzywa, które nie jest ani zielone, ani duże (dziecko ma wskazać warzywo pozbawione obu tych cech). Zależnie od możliwości intelektualnych dzieci można w tej wersji ćwiczenia posłużyć się rekwizytami (np. warzywami, owocami lub ich zdjęcia$\mathrm{mi}$ ), tak by dziecko wybierało nazwy ze zbioru zamkniętego.

To ćwiczenie warto wykonywać w grupie, tak by jedno dziecko zadawało drugiemu „zagadkę” zgodnie z przyjętą strukturą (np. ani..., ani...).

\section{Ćwiczenie 5}

Instrukcja podawana przez prowadzącego: Dam ci słowa zapisane na kartkach. Spróbuj ułożyć z nich poprawne zdanie.

W przypadku, gdy dziecko nie potrafi czytać, dorosły czyta po kilka wyrazów, np. „jeszcze, dlaczego”, „jeszcze nie śpisz” i zadaje dziecku pytanie: „Czy tak się mówi?” lub „Jak się mówi?”. Zależnie od umiejętności dziecka zdanie można pociąć na pojedyncze wyrazy, ale jeśli uczestnicy nie posługują się płynnie gramatyką, możemy nie rozcinać wyrażeń przyimkowych lub trudniejszych, mniej oczywistych połączeń (zdania złożone). Zaczynamy od zdań krótkich i łatwych, np.

Dlaczego jeszcze nie śpisz?

Bardzo lubię lody śmietankowe.

W miarę wykonywania kolejnych ćwiczeń utrudniamy zdania, stopniowo dochodząc do zdań złożonych i wielokrotnie złożonych np.

Kiedy byłem młodszy, bardzo lubiłem wspinać się na drzewa, mimo że czasem $\mathrm{z}$ nich spadałem. 
Ćwiczenie kształtuje świadomość fleksji i składni zdań.

\section{Ćwiczenie 6}

Instrukcja podawana przez prowadzącego: Ułóż zdanie $\mathrm{z}$ podanym przeze mnie wyrazem. $\mathrm{Np}$. kiedy powiem słowo jabłko, ty możesz wymyślić zdanie: $\mathrm{Na}$ drzewie rosło czerwone jabłko.

W przypadku dzieci starszych lub dzieci, których umiejętności na to pozwalają, można układać zdania z dwoma lub trzema wyrazami bądź podawać dziecku nie tylko rzeczowniki, przymiotniki, czasowniki, lecz także przyimki, spójniki. Przykładowo: Ułóż zdanie ze słowami którego i więc. Zależnie od wieku i umiejętności można się umówić z dzieckiem, czy w zdaniu można zmieniać formę gramatyczną wyrazu wskazanego przez prowadzącego.

\section{Ćwiczenie 7}

Instrukcja: Spróbuj w usłyszanym zdaniu zamienić jak najwięcej słów na inne, ale tak, żeby znaczenie całego zdania się nie zmieniło lub zmieniło jak najmniej (stosowanie synonimów).

Janek wypił tylko trochę picia podczas przerwy.
Janek wypił odrobinę soku między lekcjami.

Asia zadzwoniła do Ewy, żeby sprawdzić, czy było coś zadane do domu.

Asia zatelefonowała do Ewy, by zapytać o pracę domową.

Praktyka kliniczna wskazuje na efektywność wszystkich grup ćwiczeń. Obserwacje długoterminowe dotyczące postępów pacjentów wskazują jednak na dużą zależność czasu utrzymywania się efektów ćwiczeń (lub dalszego ich rozwoju) od czynników takich jak: nawyki dziecka, czas korzystania przez nie z urządzeń elektronicznych i stymulacja środowiskowa. $\mathrm{Z}$ obserwacji i informacji uzyskiwanych od rodziców można wnosić, że zainteresowanie światem, różnymi aspektami życia, dążenie do samodzielności, poczucie odpowiedzialności za siebie i innych, bezpośredni kontakt z osobami w różnym wieku, mają pozytywny wpływ zarówno na rozwój zasobu słownika, percepcji słuchowej, komunikacji, jak i rozwój psychospołeczny. U osób często używających urządzeń elektronicznych (np. smartfon, tablet, telewizor), być może ze względu na brak konieczności werbalnego komunikowania się z urządzeniem, znacznie częściej obserwuje się brak rozwoju lub regres umiejętności zdobytych podczas treningu.

\section{Piśmiennictwo:}

1. American Speech-Language-, Hearing Association, American Speech-Language-. (Central) Auditory Processing Disorders The Role of the Audiologist [Position Statement], 2005.

2. Surmanowicz-Demenko G. Percepcja mowy w zarysie. W: Obrębowski A, red. Wybrane zagadnienia $\mathrm{z}$ audiometrii mowy. Poznań; 2011, s. 28-51.

3. Fowler CA. An event approach to the study of speech perception from a direct-realist perspective. J Phon, 2003(31): 305.

4. Massaro DW. Testing between the TRACE Model and the Fuzzy Logical Model of Speech perception. Cognit Psychol, 1989; 21: 398 .

5. Kenneth N. Stevens. Toward a model of lexical access based on acoustic landmarks and distinctive features. Acoust Soc Am, 2002; 111(4): 1872-91.

6. Liberman AM. Some results of research on speech peception. J Acoust Soc Am, 1957; 29: 117.

7. Grabias S. Teoria zaburzeń mowy. Perspektywy badań, typologie zaburzeń, procedury postępowania logopedycznego. W: Grabias S, Kurkowski M, red. Logopedia. Teoria zaburzeń mowy. Lublin; 2012, s. 9.

8. Kurkowski M. Audiogenne uwarunkowania zaburzeń komunikacji językowej. Lublin: Wydawnictwo Uniwersytetu Marii Curie-Skłodowskiej, 2013.

9. Senderski A, McPherson DL, Kochanek K, Skarżyński H. Wpływ uwagi na parametry potencjałów poznawczych rejestrowanych dla zdań naturalnych prezentowanych w modalności słuchowej. Audiofonologia, 2005; 27: 1-9.
10. Fiez JA, Raichle ME, Miezin FM, Petersen SE, Tallal P, Katz WF. PET Studies of Auditory and Phonological Processing: Effects of Stimulus Characteristics and Task Demands. J Cogn Neurosci, 1995; 7(3): 357-75.

11. Trochymiuk A. Sprawności językowe a sprawności komunikacyjne w rozwoju mowy dziecka z uszkodzonym narządem słuchu. Studium przypadku. Audiofonologia, 2001; 19: 121-53.

12. Krasowicz-Kupis G. SLI i inne zaburzenia językowe. Od badań mózgu do praktyki psychologicznej. Sopot: Gdańskie Wydawnictwo Psychologiczne; 2012.

13. Bellis TJ. Assessment and Management of Central Auditory Processing Disorders in the Educational Setting: From Science to Practice. Clifton Park: NY: Thomson/Delmar Learning; 2003.

14. Wysocka M. Prozodia mowy w percepcji dzieci. Lublin: Wydawnictwo Uniwersytetu Marii Curie-Skłodowskiej; 2012.

15. Moncrieff D W, Wertz D. Auditory rehabilitation for interaural asymmetry: preliminary evidence of improved dichotic listening performance following intensive training. Int J Audiol, 2008; 47(2): 84-97.

16. Pawlik G. 180 ćwiczeń poprawiających koncentrację uwagi opartych na analizatorze słuchowym. Ćwiczenia dla młodzieży i dorosłych. Zamość: Atut Biuro Promocji; 2012.

17. Graban J, Sprawka R. Trening słuchu. Ćwiczenia rozwijające percepcję słuchową u dzieci. Harmonia; 2013.

18. Słodownik-Rycaj E. Gry i zabawy językowe. Jak pomagać dziecku w przyswajaniu języka. Warszawa: Żak Wydawnictwo Akademickie; 2001.

19. Jachimska M. Grupa bawi się i pracuje. Wałbrzych: Oficyna Wydawnicza Unus; 1994. 
